\title{
Are There Gender Differences in Sustainable Entrepreneurship Indicators Amongst SMEs in South Africa? Application of MANOVA
}

\author{
Ogujiuba Kanayo ${ }^{1,2}$, Ebenezer Olamide ${ }^{1}$ Isaac Agholor $^{3} \&$ Estelle Boshoff $^{1}$ \\ ${ }^{1}$ School of Development Studies, University of Mpumalanga, South Africa \\ ${ }^{2}$ Senior Research Fellow, University of the Western Cape, South Africa \\ ${ }^{3}$ School of Agriculture, University of Mpumalanga, South Africa \\ Correspondence: Ogujiuba Kanayo, School of Development Studies, Faculty of Economics, Development and \\ Business Sciences, University of Mpumalanga, South Africa. E-mail: Kanayo.Ogujiuba@ump.ac.za
}

Received: June 6, 2021

doi:10.5430/ijfr.v12n5p151
Accepted: August 4, 2021

Online Published: September 6, 2021

URL: https://doi.org/10.5430/ijfr.v12n5p151

\begin{abstract}
In addition to the contributions and relevance of entrepreneurship activities to economic growth and development of countries, various factors have equally been advanced as responsible for the success stories of entrepreneurship sustainability worldwide. However, the influence of success factors on gender ownership of entrepreneurship activities is a relatively new aspect in the field of research that has not gained much academic attention in the literature especially in South Africa. This debate is so important in the face of the various agitations for equal participation of women and the inconclusive debate that women are better managers of business enterprises. In this article, using the Multivariate Analysis of Variance (MANOVA) technique, we examined the extent to which sustainable entrepreneurship indicators (finance, social and environmental) account for any disparity in gender ownership and management of business enterprises in South Africa. A stratified sampling method was adopted for the survey. Our analytical technique (MANOVA) created a new summary dependent variable, which is a linear combination of each of our original dependent variables. Confidence intervals of $95 \%$ and margins of error (3\%) were used to validate the results. Findings indicate that the only difference that exists as per gender ownership disparity is around financial resources. There is therefore a need to realign programmes and policies to reduce this gendered inequality.
\end{abstract}

Keywords: entrepreneurship, South Africa, business success

JEL: C20, D20, D60

\section{Introduction}

In as much as resources are available to both men and women to start their businesses, women entrepreneurs still perform low compared to their male counterparts when measured by job creation, returns, sales turnover and sales revenues (Losccoco, Kary \& Leicht 1993). A study by Mersha and Sriram (2018) also indicated that men still outperformed their female counterparts when focusing on the following three entrepreneurial success measures namely, sales growth, growth in the number of employees, and profitability. Previous research probing the performance variance of both businesses owned by females and males using size and growth indicators suggest that women-owned firms underperform compared to men owned firms (Coleman 2007a). Various reports of women owners of Small and Medium Enterprises (SMEs) state that starting and operating a new venture is more challenging for women than men. Comparatively, women unlike men, are involved in different businesses which tend to be significantly smaller than firms owned by men and remain heavily concentrated in the service and retail sectors (Du Rietz and Henrekon (2000); Kalleberg and Leicht (1991); Losccoco et al., (1993). Furthermore, females have less resources which are vital to start a business, fewer prospects, different intents and social networks that can simplify the start of a business compared to males. The above differences have been accredited to structural positions that females and males occupy in place of work and society, while others attribute them to interpersonal alignment, (Cartel \& Millin 2007). Mukhtar (2002) asserts that the issue of gender differences is based on social construction theory which relates men to maleness and women to femaleness. This discrepancy has been reflected in past studies to influence performance of women-owned and men-owned enterprises (Irene 2017). Kolvevereid (1992), in Norway 
indicated that men entrepreneurs were more likely to register growth than women entrepreneurs though, there were not a significant number of differences shown. A few past studies have examined why women do not perform as men in businesses while considering the resource use perspective in a more general way. These resources (formal forms of finance) have long been argued to be essential in small business firms. Another significant area of women underperformance is reflected on how they access finance for starting and operating business units. Previous research found that women were more likely to use informal methods to finance their businesses. Past research indicates that women owned small businesses continue to lag in terms of growth and size compared to men owned small businesses (Coleman 2007a). Past studies indicate that women have fewer resources than men when focusing on specific resources like financial resources which affect performance of SMEs (Brush \& Changati 2006, Schutjens \& Wever 2000). Howbeit, South Africa presents social and economic structures that differ from many developed and developing countries and there is little or no research on the performance of South African female-owned versus male-owned SMEs as per sustainable entrepreneurship indicators.

While the contributions and relevance of entrepreneurship activities to the economic growth and development of countries have been well researched, various factors have equally been advanced as responsible for the success stories of entrepreneurship sustainability worldwide. These factors cut across the spectrum of poverty alleviation, job creation, economic growth stimulation, innovation, welfare enhancement and income generation to the government in form of tax payment (Mandipaka 2014). In the same vein, some of the influencing success factors include finance (Fowowe 2017, Herrington \& Coduras 2019, Brixiova et al. 2020), social (Naidu \& Chand 2015, Ratten \& Dana 2017 and Mari et al. 2017), environmental (Shava \& Rungani 2016 and Bastian et al. 2019), government policy (Akinyemi \& Adejumo 2018), external (Bastian et al. 2019 and Mahadea \& Khumalo 2020), internal (Debnath et al. 2019 and Ogujiuba 2020) and corporate factors (Arun et al .2015 and Orazali 2019). These factors affect business activities in countries differently either in terms of sustainability, management or ownership (Ogujiuba et al. 2020). In line with global agitation for women participation in virtually every human endeavour, with entrepreneurship activities inclusive, the South Africa government enacted into law, to give room for equal opportunity for male and female ownership of business entrepreneurship.

In a study on the determinants of entrepreneurship sustainability, Hosseininia and Ramezani (2016) identified eight factors and singled out social and environmental as prominent influencing factors; using the mixed methods technique. Similarly, Ogujiuba et al. (2020) emphasized the importance of social and environmental factors as some of the driving indices to entrepreneurship sustainability in South Africa without referring to how these factors influence gender ownership and management. Abubakar (2015) opined that Africa's literacy in finance could be an antidote against male domination of business ownership in the continent just as Dvoulety and Orel (2020) confirmed that finance is one of the reasons for gender disparity in entrepreneurship ownership and management in Africa. Further, (Faccio et al. 2016) argued that female dominated managers of business enterprises would yield better results than the male counterparts because females are more prudent in financial matters than male entrepreneurs. Yet, Urban and Nonkwelo (2020) opined that on many occasions, the conditions for accessing finance, favour males more than female entrepreneurs such that male participation and ownership of business activities are skewed towards male ownership. In a nutshell, opinions differ on the level and extent to which these trio factors account for gender disparity of business ownership and management. Women have various responsibilities in the society, when compared to men. This has driven them to approach business along their customary social roles. Social constructs variances influence performance in relation to business. The role of the household in society for both developed and developing countries indicate that some factors affect the performance of women-owned and men-owned small businesses. However, such studies comparing the performance of female-owned and male owned small firms in developing countries are limited, especially in the context of South Africa. The insufficiency of this category of research makes it exceptionally important to explain the extent to which these western findings are applicable to developing countries given the existing disparities in social structures. Furthermore, there is no existing study on South Africa that examined the effects of finance, social and environmental success factors on entrepreneurship management as well as ownership and sustainability in terms of gender disparity. In this article, we categorized our sustainable entrepreneurship indices viz-a-viz gender disparity in terms of ownership and management into financial (access to financial, financial management, risk taking ability and security for loan), social (culture, norms, inheritance, social networking) and environmental (family background, skill acquisition, economic, education and experience) in line with existing literature. We therefore, answer the following empirical questions in this article: (a) Is there any difference amongst Male and Female SME ownership as per financial resources in South Africa? (b) Is there any difference amongst Male and Female SME ownership as per Social Index (c) Is there any difference amongst Male and Female SME ownership as per Environmental index (d) What are the combined effects of finance, 
social and environmental success factors on entrepreneurship ownership and management in terms of gender disparity in South Africa?

\subsection{Sustainable Entrepreneurship, Ownership and Management of SMEs in South Africa}

There is scanty evidence on gender ownership and management in South Africa in terms of financial, social and environmental success factors. Meyer and Mostert (2016) are of the opinion that males constitute a higher percentage of business ownership in South Africa because of the conditions attached to accessing finance which favour male ownership more than female entrepreneurs. By implication, finance as a success factor to entrepreneurship sustainability, ownership and management favour females more than males. Iwu and Nxopo (2015) identified finance as a major factor for gender disparity in the ownership structure and management of business enterprise in South Africa. The findings of the mixed method technique further suggested the need to develop new policies that will further ease female accessibility to finance to reduce the imbalances in gender ownership structure and management of entrepreneurship activities in the country. Similar conclusions were drawn from the study by Baliyan, Mosia and Baliya (2020) in Botswana where finance was found as one of the major attitudinal factors responsible for gender inequality in ownership structure and management of entrepreneurship activities. Mahadea and Khumalo (2020) observed storage and infrastructural challenges as some of the factors inhibiting the progress and sustainability of entrepreneurship activities in South Africa. Finance was shown as a major predicament to female ownership of small and medium scale enterprises in Gambia as against male entrepreneurship participation (Fall 2020). Urban and Nonkwelo (2020) concluded that females are always at a disadvantage when it comes to business ownership and management in South Africa. Brijlal, Naicker and Peters (2013) linked business environment in South Africa to its productivity and discovered that the environment influences performance and that the performance is a positive function of gender ownership. However, the study noted that there were no differential effects on output in terms of educational attainment as a social factor and entrepreneurial capability, whether the owner is a male or female. In essence, education has equal effect on output, irrespective of gender ownership and management of an enterprise. On the contrary, Chirwa (2008) reported that gender ownership and management affect output in Malawi differently in that the females performed better than male entrepreneurs owing to the level of education.

The success story of a construction entrepreneur in South Africa was examined by Windapo (2018) and reported that education as a social index has no effect on sustainability growth of the business outfit as the owner did not possess any basic education. Mamabolo et al. (2017) observed in an evaluation of the success factors to entrepreneurship sustainability in South Africa that education has no differential effect on performance and management based on gender ownership. Similarly, Derera et al. (2014) confirmed in a study that discrimination against females in lending operation of banks in South Africa put them at a disadvantage as against their male counterparts and ultimately in ownership structure. While it is evident that much had been researched on entrepreneurship as an important means to economic growth, poverty reduction, employment generation; the gender disparity in terms of business ownership and management with finance, social and environment as success factors to entrepreneurship sustainability is still a missing gap.

\section{Effect of Gender on Sustainable Entrepreneurship Indicators}

Gender disparity in participation, management, ownership and entrepreneurship sustainability has produced mixed reactions in the business world of literature. While some studies reported that females are better managers/owners of business enterprises (Kobeissi 2010, Faccio et al. 2016 and Mari et al. 2016), some agreed that male entrepreneurs perform better than the female owners (Belitski \& Desai 2019, Brixiova et al. 2020). However, the extent to which finance, social and environmental factors account for the disparity in the ownership structure of SMEs in South Africa is a missing link that has not received researchers' attention and hence, this study aims at shedding more light on it. Factors such as social, environmental, finance, government policies and support, external and internal, experience as well as skill acquisition have been used as the measuring parameters to substantiate the claims on gender disparity of ownership, management, performance and entrepreneurship sustainability (Shava \& Rungani 2014, Chaudhuri et al. 2018). In a study where 2000 entrepreneurs from 24 countries were included, Belaounia et al. (2020) categorized business ownership and management into those that were female dominated and those with less female participatory management. They confirmed a better result for female dominated organizations using performance index, earnings management and risk-taking ability than the male managers. One major sustainable entrepreneurship index that accounted for the gender disparity in output, according to this study, was the degree of accessibility to education; a social and environmental factor that has been attributed to entrepreneurship sustainability (Shava \& Rungani 2014, Hosseininia \& Ramezani 2016). 
Finance and Entrepreneurship Sustainability: While finance has been acknowledged as one of the major success factors that accounted for gender disparity of business ownership, opinions differ on the extent to which it aided this disparity in ownership. This ranges from risk taking ability (Nelson 2015, Faccio et al. 2016 and Zalata et al. 2018) to financial prudency/accessibility (Carter \& Rosa 1998, Presbitero et al. 2014, Baafi 2015, Reguera-Alvarado et al. 2015, Fowowe 2017 and Muhammad et al. 2018) and dividend/earnings management (Faccio et al. 2016, Gull. 2017 and Orazalin 2019). Zalata et al. (2018) opined that the risk avert nature of women is an advantage in the management of entrepreneurship finances, especially in the area of financial reporting. The more risk averse a manager is, the better for the organization in that unnecessary risk adventures are avoided which will translate into prudent earnings management. Therefore, the study substantiated that since female entrepreneurship managers are more risk averse than their male counterpart, they are better managers of business enterprises in terms of prudent financial management, satisfactory dividend policy and boardroom politics; all of which are ingredients of a successful entrepreneurship sustainability. Similarly, but on the composition of entrepreneurship ownership and management, Orazalin (2019) found that mixed-gender ownership yielded better result in terms of earnings management than male or female concentrated teams. Faccio et al. (2016) documented in their study on gender disparity in capital efficiency allocation and risk bearing, that entrepreneurship sustainability management under the ownership of a female has lesser earnings volatility. On the contrary, Chaudhuri et al. (2018) and Wellalage and Locke (2017) discovered in their studies that accessibility to finance accounted for higher male entrepreneurs than the female counterpart which form another basis for better ownership and performance by males than females in entrepreneurship management. Presbitero et al. (2014) further confirmed that there is disparity in gender management of financial resources of business enterprises towards entrepreneurship sustainability. In Ghana, Abor and Biekpe (2006) and Orser et al. (2006) investigated whether there were differential effects on the use of external debt by male and female entrepreneurs cum ownership and concluded that female entrepreneurs are not too disposed to the use of external debt than their male counterparts because of discrimination by external debt lenders. This resulted into skewed preference for male ownership, accessibility and management in terms of financial support than female managers. Brixiova et al. (2020) focused on disparity in land ownership as security for loan accessibility viz-a-viz entrepreneurship sustainability in three Southern Africa countries of eSwatini, Lesotho and Zimbabwe and claimed that female entrepreneurs are at disadvantage and as such, could not own or manage businesses in comparative terms.

Muhammad et al. (2018) reported that finance as an output of entrepreneurship performance has no gender connotation as well as any coloration in assessing entrepreneurship sustainability in a study that employed a multiple regression method of estimation. Extending the financial success factor to the management of banks in Jordan, the need to increase female participation in banks' structure was thence solicited for. Belitski and Desai (2019) investigated the role of females in business ownership in three Asian countries (Bangladesh, India and Pakistan) and stressed the importance of gender in firm ownership viz-a-viz growth and finance accessibility. On gender ownership versus finance and growth of firms, a positive relationship was shown for Bangladesh while in India and Pakistan, the relationship was negative against female participation. In a nutshell, firms' sustainability in terms of male ownership and management cum finance accessibility resulted into higher productivity in India and Pakistan while the reverse holds for Bangladesh. Other studies that pointed finance accessibility in favour of male as against female entrepreneurship ownership and management include Baliamoune-Lutz and Lutz (2017), Nieman and Nieuwenhuizen (2014). Concluding on the financial performance of some selected companies in Malaysia, Marimamuthu and Kolandaisamy (2009) observed that there was inconclusiveness in terms of gender ownership and management of entrepreneurship activities in the study.

Social and Environmental Factors: Ogujiuba et al. (2020) listed environment and social factors among the driving variables responsible for entrepreneurship sustainability in South Africa without gender connotation. Hosseininia and Ramezani (2016) combined social and environmental as twin interwoven factors in their analysis of influencing factors of entrepreneurship sustainability in Iran and found that certain features such as education and experience, which are components of social and environmental factors, impact positively and significantly on entrepreneurship sustainability in Iran. Kobeissi (2010) identified education, economic activities, economic environment, earnings ratio, rate of fertility and gender empowerment as some of the components of social and environmental factors to entrepreneurship sustainability.

One important social factor in the literature is the issue of women with dual roles as managers and owners of business enterprises, a factor that was researched as having a direct relationship with entrepreneurship sustainability and successfulness in the world of entrepreneurism. In many countries of the world especially in Africa, women are still viewed as the weaker gender to such an extent that economic activisms in the areas of business ownership, 
management and entrepreneurial entrepreneurism put them at great disadvantage (Naidu \& Chand 2015, Garcial et al. 2019 and Urban \& Nonkwelo 2020). They further observed that culture as a social factor favoured male ownership, performance and management and consequently entrepreneurship sustainability. In South Africa where there is better exposure in terms of female liberation as against many other African countries in terms of gender disparity, studies have revealed that environmental and social factors in form of domestic responsibility of women, put them at a disadvantage over their male business adventurists as far as business ownership is concerned (Motilewa \& Onakoya 2015 and Venter \& Urban 2015). Ndofirepi et al. (2018) further attributed social and environmental factors in form of education and skill acquisition to ownership and entrepreneurship participation in South Africa to tertiary institutions where it was affirmed that males are more willing to participate and own businesses than the female students. The result of the applied Mann-Whitney approach further advocated for social-driven policy that will encourage female participation and ownership for better and gender equality of business enterprises in South Africa.

Kobeissi (2010), Goldman (2016) and Meyer and Mostert (2016) recognized education, experience, training, empowerment and economic activities as gender related social factors to entrepreneurship sustainability, ownership and management. For instance, Minniti and Arenius (2003) opined that where paid jobs are available, females are less disposed to entrepreneurship activities. This is a socio-economic factor that has discouraging and negative effects on female ownership and management of enterprises. Also, Tambunan (2009) affirmed an indirect relationship between education and availability of well-paid employment in their study on the constraints to women participation in entrepreneurship activities in some Asian countries. In essence, female participation and ownership in business activities declined among the educated females in comparison to the male entrepreneurs. Whereas Kobeissi (2010) and Mari et al. (2016) recorded a positive and significant relationship between education as a social entrepreneurship factor and female participation and ownership of business enterprise. Hence, Mari et al. (2016) suggested continued entrepreneurship education for female entrepreneurs in order to encourage their participation in entrepreneurship activities. As a social entrepreneurship sustainability factor, Powell and Eddleston (2013) observed that experience through family tie exhibits positive association with the success of entrepreneurship activities in favour of females than their male counterparts in a study on gender disparity influence on the ownership and management of business organizations.

Mixed results emanated from the logistic regression method as applied by Noguera et al. (2012) on the combined effects of financial, social and environmental factors to entrepreneurship sustainability. The study revealed that family and social networking have, when compared to male entrepreneur, a positive influence towards female ownership and management of entrepreneurship activities while finance as a success factor contributed positively to male entrepreneurs in terms of accessibility. Shava and Rungani (2016) examined experience as an environmental success factor to business performance (as it applies to)_gender disparity and came with the finding that experience has no effect in the performance of small and medium scale enterprises evaluation. The study which further sought to know the extent to which gender experience influence performance (if there was any after all) concluded that there is no gap as far as experience is concerned whether in low, middle or high phase of acquisition. Bastian et al. (2019) categorised gender inequality as an environmental success factor to the management and entrepreneurship sustainability of business enterprises and discovered that inequality has equal effects on male and female participation in entrepreneurial activities. According to Venter and Urban (2015), social and environmental culture, which allow more female participation in entrepreneurship activities, were found as having a positive relationship. The study by Felix and David (2019) corroborated this opinion in a study where female involvement in business ownership and management yielded better results than those dominated by males.

It is evident from above reviews that three major sustainable entrepreneurship indicators namely finance, social and environmental echoed and re-echoed in terms of gender differences in business ownership structure. Not only that, the extent to which they influence business ownership in terms of gender disparity was also emphasised. It is therefore obvious that investigating the degree to which these three indicators account for disparity in ownership structure of SMEs in South Africa is a worthwhile exercise. Therefore, the next section of the study employed econometric analysis to support or prove otherwise some or all the reviewed findings.

\section{Data and Methods}

This study adopted a stratified sampling approach, based on the theory of probability. Using this method, gives the best chance to create a sample that is truly representative of the population. The respondents included owner-managers and supervisors from SMEs active in Mpumalanga Province. The EU's description of SMEs, as medium and small-sized enterprises with less than 250 or 50 persons, was the basis for the survey. Accordingly, 3000 SMEs with less than 250 employees were chosen as the population target. The population target (SMEs) was 
divided into groups (based on size) and a sample was selected from each stratum. This method is used because it enables researchers to obtain a sample population that best represents the entire population being studied; making sure that each subgroup of interest is represented. With an estimated population size of 3000 SMEs operating in Nelspruit, a margin of error of 3\% and 95\% confidence level, the required sample size was estimated to about 790 . Thus, making a provision of $50 \%$ response rate, a total number of 1,580 questionnaires were distributed. As per above, the sample for the survey was selected in two stages. This was done by dividing SMEs into homogenous 30 groups (High, Medium and low Profits) of 100 per group. In the second stage, a simple random sampling was used to estimate statistical measures for each subgroup proportional to the population size of 3000 SMEs. In this stage, a fixed number of 53 SMEs were drawn from each stratum using systematic sampling) totalling to 1590 SMEs. Finally, 980 responses were received. This approach was chosen to ensure that every population characteristic is properly represented in the sample. The final sample size margin of error at $95 \%$ confidence level was $2.57 \%$. Even so, several authors incline to different rubrics concerning the total number of cases requisite for multiple regression. Stevens (1996) recommends that for social science studies, about 15 respondents per predictor are needed for a reliable equation. However, our sample size selection is guided by Tabachnick and Fidell (2001) with the [formula $\mathrm{N}>50+8 \mathrm{~m}$ (where $\mathrm{m}=$ number of independent variables) for calculating sample size requirements. In our context, we have one (1) independent variable, thus the minimum sample size will be 58 . Nonetheless, we have 950 cases as our sample size.

Multivariate Analysis of Variance (MANOVA) is an extension of analysis of variance for use when there is more than one (dependent variable. These dependent variables are related in some way. This technique compares the groups and indicates whether the mean differences between the groups on the combination of dependent variables is likely to have occurred by chance. To do this, MANOVA creates a new summary of dependent variables, which is a linear combination of each of our original dependent variables. MANOVA indicates if there is a significant difference between our groups on these composite dependent variables; and provides the univariate results for each of our dependent variables separately. The advantage of using MANOVA is that it 'controls' for this increased risk of Type 1 error.

\section{Results and Discussion}

Table 1. Between-subjects factors and descriptive statistics

\begin{tabular}{|c|c|c|c|c|}
\hline & & Value Label & $\mathrm{N}$ & \\
\hline \multirow[t]{3}{*}{ Gender } & 1 & Male & 493 & \\
\hline & 2 & Female & 414 & \\
\hline & Gender & Mean & Std. Deviation & $\mathrm{N}$ \\
\hline \multirow{3}{*}{$\begin{array}{l}\text { Financial Resources } \\
\text { Index Score }\end{array}$} & Male & 23.01 & 4.468 & 493 \\
\hline & Female & 22.07 & 3.935 & 414 \\
\hline & Total & 22.58 & 4.257 & 907 \\
\hline \multirow[t]{3}{*}{ Social Index Score } & Male & 15.37 & 3.506 & 493 \\
\hline & Female & 15.30 & 3.190 & 414 \\
\hline & Total & 15.34 & 3.364 & 907 \\
\hline Environmental & Male & 15.36 & 3.506 & 493 \\
\hline Resources Index & Female & 15.43 & 3.258 & 414 \\
\hline Score & Total & 15.39 & 3.393 & 907 \\
\hline
\end{tabular}

The above table checks that our $\mathrm{N}$ values correspond to our sample. We have more subjects (cases) in each cell than the number of dependent variables. Since we have over 30, then any violation of normality or equality of variance that may exist is not going to matter too much. 
Table 2. Box's Test of Equality of Covariance Matrices

\begin{tabular}{lr}
\hline Box's M & 13.524 \\
\hline F & 2.246 \\
\hline df1 & 6 \\
\hline df2 & 5480744.119 \\
\hline Sig. & .036 \\
\hline a. Design: Intercept + Sex & \\
\hline
\end{tabular}

The above table tests the null hypothesis that the observed covariance matrices of the dependent variables are equal across groups. The output box labelled Box's Test of Equality of Covariance Matrices indicates whether our data violates the assumption of homogeneity of variance covariance matrices. Thus, since the Sig. value (0.036) is larger than .001 , we have not violated the assumption.

Table 3. Multivariate Tests ${ }^{\mathrm{a}}$

\begin{tabular}{|c|c|c|c|c|c|c|c|}
\hline \multirow[t]{2}{*}{ Effect } & & \multicolumn{5}{|c|}{ Hypothesis } & \multirow{2}{*}{$\begin{array}{r}\text { Partial Eta } \\
\text { Squared }\end{array}$} \\
\hline & & Value & $\mathrm{F}$ & df & Error df & Sig. & \\
\hline \multirow[t]{7}{*}{ Intercept } & Pillai's Trace & .982 & $16150.551^{\mathrm{b}}$ & 3.000 & 903.000 & .000 & .982 \\
\hline & Wilks' & .018 & $16150.551^{\mathrm{b}}$ & 3.000 & 903.000 & .000 & .982 \\
\hline & Lambda & & & & & & \\
\hline & Hotelling's & 53.656 & $16150.551^{\mathrm{b}}$ & 3.000 & 903.000 & .000 & .982 \\
\hline & Trace & & & & & & \\
\hline & Roy's Largest & 53.656 & $16150.551^{\mathrm{b}}$ & 3.000 & 903.000 & .000 & .982 \\
\hline & Root & & & & & & \\
\hline \multirow[t]{7}{*}{ Gender } & Pillai's Trace & .012 & $3.762^{\mathrm{b}}$ & 3.000 & 903.000 & .011 & .012 \\
\hline & Wilks' & .988 & $3.762^{b}$ & 3.000 & 903.000 & .011 & .012 \\
\hline & $L a m b d a$ & & & & & & \\
\hline & Hotelling's & .012 & $3.762^{\mathrm{b}}$ & 3.000 & 903.000 & .011 & .012 \\
\hline & Trace & & & & & & \\
\hline & Roy's Largest & .012 & $3.762^{\mathrm{b}}$ & 3.000 & 903.000 & .011 & .012 \\
\hline & Root & & & & & & \\
\hline \multicolumn{8}{|c|}{ a. Design: Intercept + Gender } \\
\hline \multicolumn{8}{|c|}{ b. Exact statistic } \\
\hline
\end{tabular}

The set of multivariate tests of significance shown above, indicates whether there are statistically significant differences among the groups on a linear combination of the dependent variables. There are a few statistics to choose from (Wilks' Lambda, Hotelling's Trace, Pillai's Trace). One of the most reported statistics is Wilks' Lambda. Tabachnick and Fidell (2001) recommend Wilks' Lambda for general use. The Wilks' Lambda value (0.988) significance level $(0.011)$ is less than 0.05 , thus we conclude that there is a difference among the groups. Therefore, there is a statistically significant difference between males and females in terms of their overall sustainable entrepreneurship indicators ranking. 
Table 4. Levene's Test of Equality of Error Variances ${ }^{\mathrm{a}}$

\begin{tabular}{|c|c|c|c|c|c|}
\hline & & $\begin{array}{l}\text { Levene } \\
\text { Statistic }\end{array}$ & df1 & df2 & Sig. \\
\hline \multirow{4}{*}{$\begin{array}{l}\text { Financial } \\
\text { Resources } \\
\text { Index Score }\end{array}$} & Based on Mean & 4.401 & 1 & 905 & .036 \\
\hline & Based on Median & 4.496 & 1 & 905 & .034 \\
\hline & $\begin{array}{l}\text { Based on Median and } \\
\text { with adjusted df }\end{array}$ & 4.496 & 1 & 878.366 & .034 \\
\hline & Based on trimmed mean & 4.608 & 1 & 905 & .032 \\
\hline \multirow{4}{*}{$\begin{array}{l}\text { Social Index } \\
\text { Score }\end{array}$} & Based on Mean & 5.027 & 1 & 905 & .025 \\
\hline & Based on Median & 1.826 & 1 & 905 & .177 \\
\hline & $\begin{array}{l}\text { Based on Median and } \\
\text { with adjusted df }\end{array}$ & 1.826 & 1 & 896.593 & .177 \\
\hline & Based on trimmed mean & 4.565 & 1 & 905 & .033 \\
\hline \multirow{4}{*}{$\begin{array}{l}\text { Environmental } \\
\text { Resources } \\
\text { Index Score }\end{array}$} & Based on Mean & 1.032 & 1 & 905 & .310 \\
\hline & Based on Median & .756 & 1 & 905 & .385 \\
\hline & $\begin{array}{l}\text { Based on Median and } \\
\text { with adjusted df }\end{array}$ & .756 & 1 & 890.406 & .385 \\
\hline & Based on trimmed mean & .783 & 1 & 905 & .376 \\
\hline
\end{tabular}

Furthermore, the Levene's Test of Equality of Error Variances indicates any violation of the assumption of equality of variance for that variable. The Sig. column shows that all the values are above0.05, which indicates insignificance and no violation of the assumption. In analysis, none of the variables recorded significant values; therefore, we can assume equal variances.

Table 5. Tests of between-subjects effects

\begin{tabular}{|c|c|c|c|c|c|c|c|}
\hline \multirow[b]{3}{*}{ Source } & & Type III & & \multirow{2}{*}{$\begin{array}{c}\text { Partial } \\
\text { Eta }\end{array}$} \\
\hline & Dependent & Sum of & & Mean & & & \\
\hline & Variable & Squares & df & Square & $\mathrm{F}$ & Sig. & Squared \\
\hline Corrected & Financial & $197.000^{\mathrm{a}}$ & 1 & 197.000 & 10.992 & .001 & .012 \\
\hline \multirow[t]{7}{*}{ Model } & Resources Index & & & & & & \\
\hline & Score & & & & & & \\
\hline & Social Index & $.968^{\mathrm{b}}$ & 1 & .968 & .085 & .770 & .000 \\
\hline & Score & & & & & & \\
\hline & Environmental & $1.198^{\mathrm{c}}$ & 1 & 1.198 & .104 & .747 & .000 \\
\hline & Resources Index & & & & & & \\
\hline & Score & & & & & & \\
\hline \multirow[t]{4}{*}{ Intercept } & Financial & 457318.650 & 1 & 457318.650 & 25516.562 & .000 & .966 \\
\hline & Resources Index & & & & & & \\
\hline & Score & & & & & & \\
\hline & Social Index & 211599.866 & 1 & 211599.866 & 18680.643 & .000 & .954 \\
\hline
\end{tabular}




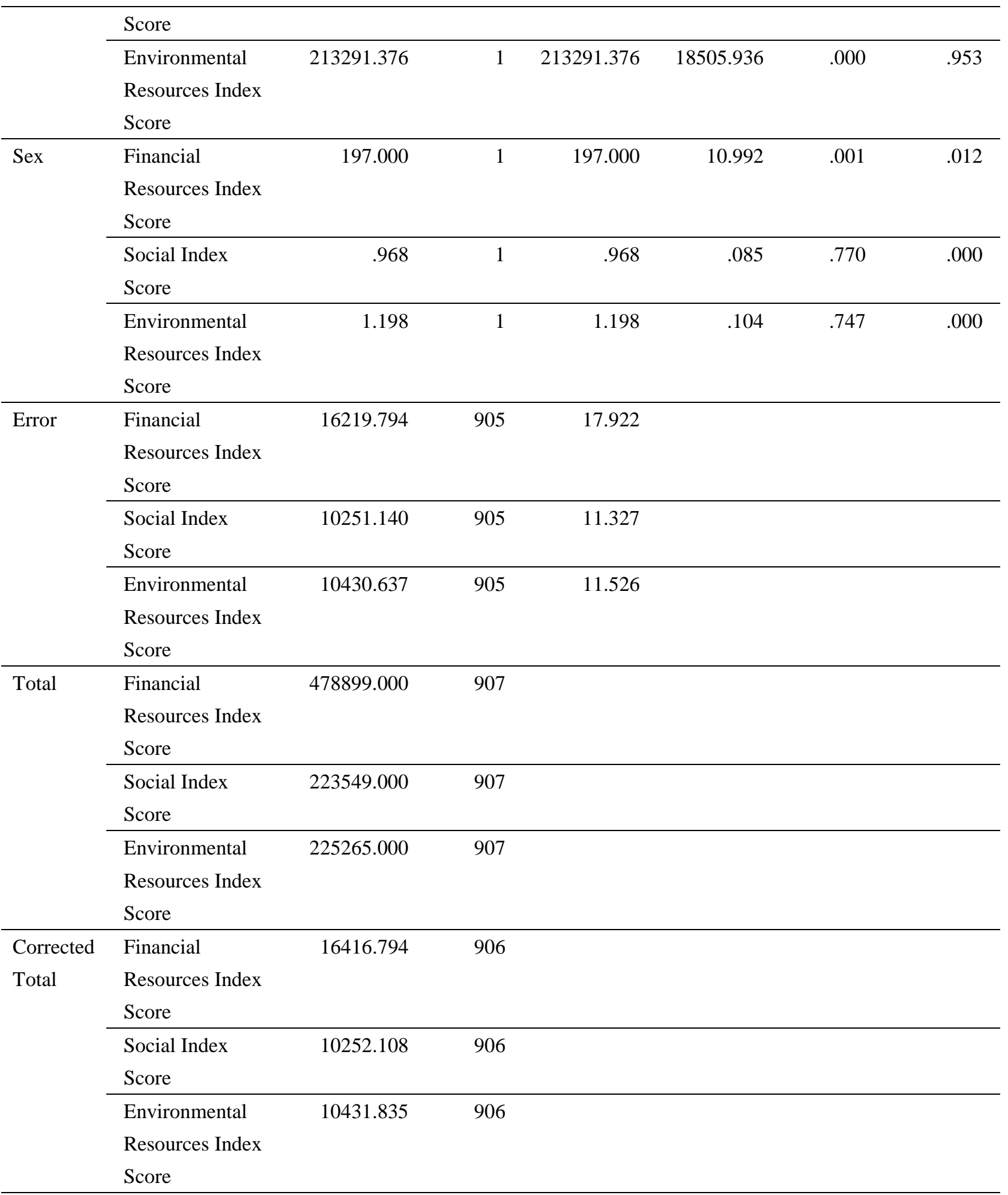

a. R Squared $=.012($ Adjusted R Squared $=.011)$

b. R Squared $=.000$ (Adjusted R Squared $=-.001$ )

c. R Squared $=.000$ (Adjusted R Squared $=-.001$ )

In-order to confirm our hypothesis, we refer to the above table (Tests of Between-Subjects Effects). The significance gives us permission to investigate further. Thus, we did set a higher alpha level to reduce the chance of a Type 1 
error (i.e., finding a significant result when there is not really one). We applied the Bonferroni adjustment. This involves dividing our original alpha level of 0.05 by the number of analyses that we intend to do (Tabachnick \& Fidell, 2001). In this case we have three dependent variables to investigate; therefore, we divided 0.05 by 3 , giving a new alpha level of 0.017. Thus, our results are considered significant only if the probability value (Sig.) is less than .017. In our analysis, only one of the dependent variables (Financial Resources Index Score) recorded a significance value less than our cut-off (with a Sig. value of .001). The importance of the impact of gender on Financial Resources can be evaluated using the effect size statistic: Partial Eta Squared. This statistic represents the proportion of the variance in the dependent variable (Financial Resources Index scores) that can be explained by the independent variable (gender). The value in this case is .012, which, according to generally accepted criteria (Cohen, 1988), is considered quite a small effect. This represents only 1.2 per cent of the variance in Financial Resources scores that are explained by gender.

Table 6. Estimated Marginal Mean (Gender)

95\% Confidence Interval

\begin{tabular}{llrrrr}
\hline $\begin{array}{l}\text { Dependent } \\
\text { Variable }\end{array}$ & Gender & Mean & Std. Error & Lower Bound & Upper Bound \\
\hline $\begin{array}{l}\text { Financial } \\
\text { Resources Index } \\
\text { Score }\end{array}$ & Male & 23.008 & .191 & 22.634 & 23.382 \\
\cline { 2 - 6 } & Female & 22.072 & .208 & 21.664 & 22.481 \\
\hline $\begin{array}{l}\text { Social Index } \\
\text { Score }\end{array}$ & Male & & & & \\
\cline { 2 - 6 } $\begin{array}{l}\text { Environmental } \\
\text { Resources Index }\end{array}$ & Male & 15.365 & .152 & 15.068 & 15.663 \\
\cline { 2 - 6 } Score & Female & 15.300 & .165 & 14.975 & 15.624 \\
\hline
\end{tabular}

Although we know that males and females differed in terms of Financial Resources Index Score, we do not know who had the higher scores. To find this out we refer to the output table provided in the section labelled Estimated Marginal Means. For Financial Resources, the mean score for males was 23.008 and for females 22.072. Although statistically significant, the actual difference in the two mean scores was very small, less than 1 scale points. Our analysis agrees that there are significant combined effects of finance, social and environmental success factors on entrepreneurship ownership and management in terms of gender disparity in South Africa amongst male and female SME owners as per social index in South Africa. In their separate studies, Goyal and Partkash (2011), Tambunan (2017) and Yunis et al. (2020) identified the dual roles of women as home keepers and business owners/managers; being major issues in their assessment of entrepreneurship ownership in relation to gender disparity. Other social factors include cultural values and norms (Amine \& Staub 2009, Okafor \& Mordi 2010, Tlaiss 2014, Naidu \& Chand 2015, and Quagrainie 2016), inheritance (Powell \& Eddleston 2013, Nelson \& Constantinidis 2017, Soebyakto et al. 2018 and Urban \& Nonkwelo 2020), traditions (Makiwane et al. 2017, Garcia et al. 2019 and Ojediran \& Anderson 2020), family sustainability (Goyal \& Parkash 2011, Kaunda \& Nkhoma 2013, Xiong et al. 2018 and Matser et al. 2020) and education (De Tienne \& Chandler 2007, Mari et al. 2016 and Shava \& Rungani 2016). All in all, these social factors have been shown empirically as having directly or indirectly influenced gender ownership and management of entrepreneurship activities of the SMEs. Our analysis confirms that there is a difference amongst male and female SME owners as per financial resources in South Africa. This is in tandem with Dvoulety and Orel (2020). They found that finance is one of the reasons for gender disparity in entrepreneurship ownership and management within Africa. Furthermore, a similar result was found in Botswana by Baliyan et al. (2020). Finance was found as one of the major factors leading to gender inequality in ownership structure of entrepreneurship activities. However, the issue of finance has received contradictory research results. While Faccio et al. (2016) argued that female managers would yield better result, Urban and Nonkwelo (2020) opined that on many occasions, the conditions for accessing finance favour males more than female entrepreneurs. Thus, ownership of business activities is skewed towards male ownership. Iwu and Nxopo (2015), Chaudhuri et al. (2018) and Wellalage and Locke (2017) identified finance as a major factor in gender disparity in the ownership structure and management of 
business enterprise. However, other studies such as Marimamuthu and Kolandaisamy (2009) and Muhammad et al. (2018) report that finance as an output of entrepreneurship performance has no gender connotation as well as any colouration in assessing entrepreneurship sustainability. Thus, there is still some inconclusiveness in terms of gender ownership and management of entrepreneurship activities as per finance. In a nutshell, opinions differ on the level and extent to which this factor account for gender disparity of business ownership and management.

Our analysis does not confirm that there is a difference amongst male and female SME owners as per social index in South Africa, which confirms earlier results by Mamabolo et al. (2017). However, findings from Shava and Rungani (2014), Hosseininia and Ramezani (2016) show opposite results. Nevertheless, Chirwa (2008) reported that gender ownership and management affect output in Malawi differently in that the females performed better than male entrepreneurs owing to the level of education. Further, our analysis is not in support of any difference amongst male and female SME owners as per environmental index in South Africa. This contrasts with Brijlal et al. (2013) that discovered that the environment influences performance and that the performance is a positive function of gender ownership. On the other hand, Shava and Rungani (2016) in their study, concluded that there is no gap as far as experience is concerned whether in low, middle or high phase of acquisition as gender ownership and management of SMEs.

\section{Summary}

Firm resources play an important role in the performance of SMEs. The low performance registered in businesses owned by women may be attributed to their different motives of starting and operating a business compared to men and the resources they possess. In this article, a one-way between-groups multivariate analysis of variance was performed to investigate gender differences in sustainable entrepreneurship. Three dependent variables were used: Financial Resources Index Score, Social Index Score and Environmental Resources Index Score. The independent variable was gender. Preliminary assumption testing was conducted to check for normality, linearity, univariate and multivariate outliers, homogeneity of variance-covariance matrices, and multicollinearity, with no serious violations noted. There was a statistically significant difference between males and females on the combined dependent variables: $F(3,903)=3.76, p=.011$; Wilks' Lambda $=.98$; partial eta squared=.012. When the results for the dependent variables were considered separately, the only difference to reach statistical significance, using a Bonferroni adjusted alpha level of .017 , was financial resources: $F(1,905)=10.992, p=.001$, partial eta squared $=.012$. An inspection of the mean scores indicated that males reported slightly higher levels of Financial Resources Index Score $(M=23.01, S D=4.468),(F=22.07, S D=3.935)$ than females. It is therefore suggested that new and innovative approaches be adopted to close the gap between the male and female entrepreneurs on the access to finance. This will reduce financial gender inequality. In as much as there are no gender differences as per social and environmental indicators of sustainable entrepreneurship, it has become imperative that a closer focus is required on the dimensions of sustainable entrepreneurship amongst SMEs in South Africa.

As a way of research gap identification, this study recognises its scope as a limitation. The province of Mpumalanga is one of the smallest provinces in South Africa whose findings cannot be taken as representing the whole country. Secondly, other indices such as climate, technological skills, business age, start-up capital (as a separate factor from finance) and regulatory framework which differ from one province to another, should be taken into consideration in future studies. This is because these indicators may have overridden effects on gender ownership structure and sustainability in South Africa as a whole.

\section{Acknowledgments}

Funding support was provided by a Research Support Grant from the University of Mpumalanga (UMP) for Research Teams of Excellence. The authors wish to thank anonymous reviewers from UMP and UWC that made useful contributions to the study.

Conflicts of Interest: The authors declare no conflict of interest.

\section{References}

Abor, J., \& Biekpe, N. (2006). SMEs' access to debt finance: A comparison of male-owned and female-owned businesses in Ghana. Entrepreneurship and Innovation, 7(2), 105-112.

Amine, L. S., \& Staub, K. M. (2009). Women entrepreneurs in sub-Saharan Africa: An institutional theory analysis from a social marketing point of view. Entrepreneurship \& Regional Development, 21(2), 183-211. https://doi.org/10.1080/08985620802182144 
Arun, T. G., Almahrog, Y. E., \& Aribi, Z. A. (2015). Female directors and earnings management: Evidence from UK companies. International Review of Financial Analysis, 39, 137-146. https://doi.org/10.1016/j.irfa.2015.03.002

Baliamoune-Lutz, M., \& Lutz, S. (2017). Financing and performance of female-owned firms in Middle Eastern and African economies. Working Paper No. 1709, Instituto Complutense de Analisis Economico, Madrid. https://doi.org/10.2139/ssrn.2907977

Baliyan, S. P., Mosia, P. A., \& Baliya, P. S. (2020). Gender differences in entrepreneurial attitudes and constraints: Do the constraints predict university agriculture graduates' attitudes towards entrepreneurship?. International Journal of Higher Education, 9(5). https://doi.org/10.5430/ijhe.v9n5p259

Bastian, B. L., Metcalfe, B. D., \& Zali, M. R. (2019). Gender inequality: entrepreneurship development in the MENA region. Sustainability.

Belaounia, S., Taob, R., \& Zhaob, H. (2020). Gender equality's impact on female directors' efficacy: A multi-country study. International Business Review, 29, 101737, https://doi.org/10.1016/j.ibusrev.2020.101737

Belitski, M., \& Desai, S. (2019). Female ownership, firm age and firm growth: a study of South Asian firms. Asia Pacific Journal of Management. https://doi.org/10.1007/s10490-019-09689-7

Brijlal, P., Naicker, V., \& Peters, R. (2013). Education and SMME business growth: A gender perspective from South Africa. International Business \& Economics Research Journal, 12(8), 855-866.

Brixiová, Z., Kangoye, T., \& Tregenna, F. (2020). Enterprising women in Southern Africa: When does land ownership matter?. Journal of Family and Economic Issues, 41, 37-51. https://doi.org/10.1007/s10834-020-09663-2

Cartel, M. N., \& Millin, W. (2007). Discontinuance among new retail: The influence of initial resources, strategy, and gender. Journal of Business Venturing, 12, 125-145.

Carter, S., \& Rosa, P. (1998). The financing of male- and female-owned businesses. Entrepreneurship and Regional Development: An International Journal, 10(3), 225-241. https://doi.org/10.1080/08985629800000013

Chaudhuri, K., Sasidharan, S., \& Raj, R. S. N. (2018). Gender, small firm ownership, and credit access: some insights from India. Small Business Economics. https://doi.org/10.1007/s11187-018-0124-3

Chirwa, E. W. (2008). Effects of gender on the performance of micro and small enterprises in Malawi. Development Southern Africa, 25(3), 347-362. https://doi.org/10.1080/03768350802212139

Coleman, S. (2007a). Women-Owned firms and growth. Journal of Business and Entrepreneurship, 19(2), 31-44.

De Tienne, D., \& Chandler, G. (2007). The role of gender in opportunity identification. Entrepreneurship Theory and Practice, 31(2), 365-386. https://doi.org/10.1111/j.1540-6520.2007.00178.x

Debnath, N. C., Patnaik, B. C. M., \& Satpathy, I. (2019). Female directorship and real earnings management in Bangladesh: Towards an analytical assessment. Management Science Letters, 9, 1723-1740.

Derera, E., Chitakunye, P., \& O’Neill, C. (2014). The impact of gender on start-up capital: A case of women entrepreneurs in South Africa. The Journal of Entrepreneurship, 23(1), 95-114.

Dvoulety, O., \& Orel, M. (2020). What drives female entrepreneurship in African developing countries?. In Dobson, S., Jones, P., Agyapong, D., \& Maas, G. (Eds.), Enterprising Africa (Edition 1, Chapter 4). Publisher: Routledge.

Faccio, M., Marchica, M-T., \& Roberto, M. (2016). CEO gender, corporate risk-taking, and the efficiency of capital allocation. Journal of Corporate Finance, 39, 193-209. https://doi.org/10.1016/j.jcorpfin.2016.02.008

Felix, E. G. S., \& David, D. S. T. (2019). Performance of family-owned firms: the impact of gender at the management level. Journal of Family Business Management, 9(2), 228-250. https://doi.org/10.1108/JFBM-10-2018-0051

Garcia, P. R. J. M., Sharma, P., De Massis, A., Wright, M., \& Scholes, L. (2019). Perceived parental behaviors and next-generation engagement in family firms: A social cognitive perspective. Entrepreneurship Theory and Practice, 43(2), 224-243.

Goldman, S. (2016). 10000 Women's project. Retrieved April 18, 2021, from http://www.goldmansachs.com/citizenship/10000women/\# 
Goyal, M., \& Parkash, J. (2011). Women entrepreneurship in India-problems and prospects. International Journal of Multidisciplinary Research, 1, 195-207.

Gull, A. A., Nekhili, M., Nagati, H., \& Chtioui, T. (2017). Beyond gender diversity: How specific attributes of female directors affect earnings management. The British Accounting Review. https://doi.org/10.1016/j.bar.2017.09.001

Hosseininia, G., \& Ramezani, A. (2016). Factors influencing sustainable entrepreneurship in small and medium-sized enterprises in Iran: A Case Study of Food Industry. Sustainability, 8, https://doi.org/10.3390/su8101010

Irene, B. N. O. (2017). Women entrepreneurship in South Africa: Understanding the role of competencies in business success. Southern African Journal of Entrepreneurship and Small Business Management, 9(1), a121. https://doi.org/10.4102/sajesbm.v9i1.121.

Iwu, C. G., \& Nxopo, Z. (2015). Determining the specific support services required by female entrepreneurs in the South African tourism industry. African Journal of Hospitality, Tourism and Leisure, 4(2).

Kalleberg, A. L., \& Leicht, T. L. (1991). Gender and organizational performance: Determinants of small business survival and success. Academy of Management Journal, 34(1), 136-161.

Kaunda, S., \& Nkhoma, A. (2013). Intergenerational survival of family businesses: factors affecting the succession success of family-owned businesses in Malawi. European Journal of Business and Management, 5(7), 157-164.

Kobeissi, N. (2010). Gender factors and female entrepreneurship: International evidence and policy implications. Journal of International Entrepreneurship, 8, 1-35. https://doi.org/10.1007/s10843-010-0045-y

Losccoco, A., Kary, A., \& Leicht, T. (1993). Gender, work-family linkages and economics success among small business owners. Journal of Marriage and Family, 55(4), 875-887.

Mahadea, D., \& Khumalo, S. (2020). Understanding the internal and external constraints to growth of microenterprise entrepreneurship in a South African provincial context: A Case of Mpumalanga-Mkhondo. Journal of Developmental Entrepreneurship, 25(2), 2050013. https://doi.org/10.1142/S1084946720500132

Makiwane, M., Gumede, N. A., Makoae, M., \& Vawda, M. (2017). Family in a changing South Africa: structures, functions and the welfare of members. South African Review of Sociology, 48(2), 49-69.

Mamabolo, M. A., Kerrin, M., \& Kele, T. (2017). Entrepreneurship management skills requirements in an emerging economy: A South African outlook. Southern African Journal of Entrepreneurship and Small Business Management, 9(1), a111. https://doi.org/10.4102/ sajesbm.v9i1.111

Mandipaka, F. (2014). Overview of women entrepreneurs in South Africa. Mediterranean Journal of Social Sciences, 5(9), 127-130. https://doi.org/10.5901/mjss.2014.v5n9p127

Mari, M., Poggesi, S., \& De Vita, L. (2016). Family embeddedness and business performance: Evidences from women-owned firms. Management Decision, 54, 476-500. https://doi.org/10.1108/MD-07-2014-0453

Marimamuthu, M., \& Kolandaisamy, I. (2009). Ethnic and gender diversity in boards of directors and their relevance to financial performance of Malaysian companies. Journal of Sustainable Development, 2(3). 139-148.

Matser, I., Bouma, J., \& Veldhuizen, E. (2020). No hard feelings? Non-succeeding siblings and their perceptions of justice in family firms. Journal of Family Business Management. https://doi.org/10.1108/JFBM-09-2018-0048

Mersha, T., \& Shriram, V. (2018). Gender, entrepreneurial characteristics, and success: Evidence from Ethiopia. Wiley online Library. https://doi.org/10.1002/tie.21984

Meyer, N., \& Mostert, C. (2016). Perceived barriers and success factors of female entrepreneurial programme. International Journal of Social and Humanity Entrepreneurial Studies, 8(1), 48-66.

Minniti, M., \& Arenius, P. (2003). Women in entrepreneurship. The entrepreneurial advantage of nations. First Annual Global Entrepreneurship Symposium.

Muhammad, S. J., Abdulattif, M., \& Zakzouk, F. (2018). The effect of gender diversity on the financial performance of Jordan Banks. Academy of Accounting and Financial Studies Journal, 22(2).

Naidu, S., \& Chand, A. (2015). National culture, gender inequality and women's success in micro, small and medium enterprises. Social Indicators Research, 130, 647-664. https://doi.org/10.1007/s11205-015-1203-3 
Ndofirepi, T. M., Rambe, P., \& Dzansi, D. Y. (2018). An exploratory study on the gender-based differences in entrepreneurial intention and its antecedents amongst students of a South African university of technology. Southern African Business Review, 22, 4345. https://doi.org/10.25159/1998-8125/4345

Nelson, J. (2015). Are women really more risk-averse than men? A re-analysis of the literature using expanded methods. Journal of Economic Surveys, 29(3), 566-585.

Nieman, G., \& Nieuwenhuizen, C. (2014). Entrepreneurship: A South African perspective. Pretoria: Van Schaik.

Noguera, M., urbano, D., \& Alvarez, C. (2012). Environmental factors and female entrepreneurship: a quantitative study in Spain. Studies in Fuzziness and Soft Computing, 243-259. https://doi.org/10.1007/978-3-642-30457-6_16

Ogujiuba, K., Nico, R., Naseer, M., Cgujiuba, C., \& Estelle, B. (2020). SMES and sustainable entrepreneurship in South Africa: Impact analysis of contextual factors in the services sector. EuroEconomica, Business Administration and Business Economics, 1(39), 7-28.

Ojediran, F., \& Anderson, A. (2020). Women's entrepreneurship in the global south: empowering and emancipating?. Administrative Science.

Okafor, C., \& Mordi, C. (2010). Women entrepreneurship development in Nigeria: The effects of environmental factors. BULETINUL, Universitatii Petrol-Gaze din Ploiesti, Economic Science Series, 62, 43-52.

Orazalin, N. (2019). Board gender diversity, corporate governance, and earnings management: Evidence from an emerging market, Gender in Management. An International Journal, 35(1), 37-60. https://doi.org/10.1108/GM-03-2018-0027

Orser, B. J., Riding, A. L., \& Manley, K. (2006). Women entrepreneurs and financial capital. Entrepreneurship Theory and Practice, 643-665.

Powell, G., \& Eddleston, K. (2013). Linking family-to-business enrichment and support to entrepreneurial success: Do female and male entrepreneurs experience different outcomes?. Journal of Business Venturing, 28, 261-280.

Presbitero, A. F., Rabellotti, R., \& Piras, C. (2014). Barking up the wrong tree? Measuring gender gaps in firm's access to finance. Journal of Development Studies, 50(10), 1430-1444. https://doi.org/10.1080/00220388.2014.940914

Quagrainie, F. A. (2016). Institutional approach and competitive behaviours of informal Ghanaian women entrepreneurs. International Journal of Entrepreneurship and Small Business, 28, 323-38.

Ratten, V., \& Dana, L.-P. (2017). Gendered perspective of indigenous entrepreneurship. Small Enterprise Research, 24, 62-72. https://doi.org/10.1080/13215906.2017.1289858

Reguera-Alvarado, N., de Fuentesi, P., \& Laffarga, J. (2015). Does board gender diversity influence financial performance? Evidence from Spain. Journal of Business Ethics. https://doi.org/10.1007/s10551-015-2735-9

Schutjens, V. A. J., \& Wever, E. (2000). Determinants of new firm success. Papers in Regional Science, 79, 135-159.

Shava, H., \& Rungani, E. C. (2014). Gender differences in business related experience amongst SMMEs owners in King William town, South Africa: A comparative analysis. Mediterranean Journal of Social Sciences, 5(20). https://doi.org/10.5901/mjss.2014.v5n20p2687

Shava, H., \& Rungani, E. C. (2016). Influence of gender on SME performance in emerging economies. Acta Commercii, 16(1), a408. https://doi.org/10.4102/ ac.v16i1.408

Soebyakto, B. B., Mukhtarudddin, D. H., Dewi, K., \& Pratama, A. F. (2018). Female commissioner and director, and earnings management: Study on manufacturing companies Listed on Indonesia Stock Exchange. Academy of Accounting and Financial Studies Journal, 2(4).

Tambunan T. (2009). Women entrepreneurship in Asian developing countries: Their development and main constraints. Journal of Development and Agricultural Economics, 1(2), 027-040.

Tambunan, T. (2017). Women entrepreneurship in MSEs in Indonesia: Their motivation and main constraints. Journal of Women's Entrepreneurship and Education, 1(22), 56-86.

Tlaiss, H. A. (2014). Women's entrepreneurship, barriers and culture: Insights from the United Arab Emirates. The Journal of Entrepreneurship, 23(2), 289-320. 
Urban, B., \& Nonkwelo, R. P. (2020), Intra-family dynamics and succession planning in family businesses in South Africa: the daughter as a potential successor. Journal of Family Business Management. https://doi.org/10.1108/JFBM-08-2020-0084

Venter, R., \& Urban, B. (2015). Entrepreneurship Theory in Practice (3rd ed.). Oxford University Press, Cape Town.

Wellalage, N., \& Locke, S. (2017). Access to credit by SMEs in South Asia: Do women entrepreneurs face discrimination?. Research in International Business and Finance, (41), 336-346. https://doi.org/10.1016/j.ribaf.2017.04.053

Windapo, A. (2018). Entrepreneurial factors affecting the sustainable growth and success of a South African construction company, Sustainability, 10, 1276. https://doi.org/10.3390/su10041276

Xiong, L., Ukanwa, I., \& Anderson, A. R. (2018). Institutional influence and the role of family in poor women's micropreneurship. International Journal of Entrepreneurial Behavior and Research, 26, 122-40.

Yunis, M. S., Hina, H., \& Sajida, T. (2020). The gendering of context: A fresh perspective of women social enterprise in Pakistan. Business and Economic Review, 12, 25-48.

Zalata, A. M., Ntim, C., Aboud, A., \& Gyapong, E. (2018). Female CEOs and core earnings quality: New evidence on the ethics versus risk-aversion puzzle. Journal of Business Ethics. https://doi.org/10.1007/s10551-018-3918-y

\section{Copyrights}

Copyright for this article is retained by the author(s), with first publication rights granted to the journal.

This is an open-access article distributed under the terms and conditions of the Creative Commons Attribution license (http://creativecommons.org/licenses/by/4.0/). 